\author{
И. В. Просвирякова \\ Российский экономический университет имени Г. В. Плеханова, \\ Москва, Россия
}

На современном российском рынке ретейла, который является неотъемлемой частью общества, представлено множество разнообразных компаний. Для того чтобы успешно продолжать свою деятельность, компаниям необходимо анализировать большое количество финансовых показателей, тесно взаимосвязанных между собой. Изменение одного из них влечет за собой ряд изменений в других, что свидетельствует о важности выбора нужного показателя, который способствует повышению эффективности деятельности компании в целом. Основная задача данной статьи - раскрытие важнейших финансовых показателей компаний ретейла, на основании которых строится политика эффективного управления. Автором исследуются точки торможения, служащие препятствием для более эффективного развития компаний в сфере ретейла, а также раскрываются направления, следуя которым компании смогут улучшить результаты своей деятельности. Рассматриваются крупнейшие игроки рынка ретейла - ПАО «Магнит», ПАО «Детский Мир», ПАО «М.Видео» и ООО «Лента». На основании открытых данных их отчетности рассчитываются показатели рентабельности, оборачиваемости, финансовой устойчивости, средневзвешенной стоимости капитала, определяется эффект финансового рычага и предлагаются направления, в которых компании, изменяя свою действующую политику, могут повысить эффективность деятельности.

Ключевые слова: рентабельность активов, рентабельность собственного капитала, эффект финансового рычага, средневзвешенная стоимость капитала, коэффициент автономии, коэффициент покрытия инвестиций, коэффициент оборачиваемости.

\title{
ESTIMATING FINANCE RESULTS OF RETAIL COMPANIES
}

\author{
Irina V. Prosviriakova \\ Plekhanov Russian University of Economics, Moscow, Russia
}

On present day Russian retail trade market, which is an integral part of society, there are a lot of different companies. To continue their work companies shall analyze numerous finance figures that are closely connected with each other. Changes in one of them can cause changes in others, which shows the importance of choosing an adequate indicator that could foster higher efficiency of company' work in general. The principle goal of the article is to show the essential finance indicators of retail companies, on whose foundation policy of efficient management is built. The author studies drag points that hinder more efficient development of the company in the field of retail trade, he also reveals the lines that can help companies improve their work. The biggest participants of retail market are analyzed, such companies as 'Magnit', 'Detskiy Mir', 'M. Video', 'Lenta'. On the basis of open data of their accounting reports the article studies figures of their profitability, turnover, finance stability, average-weighted capital value, defines the effect of finance leverage and proposes lines in which companies can raise their efficiency by changing the current policy.

Keywords: asset profitability, own capital profitability, effect of finance leverage, average-weighted capital value, autonomy index, investment cover index, turnover index.

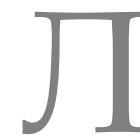
юбая компания отражает результаты своей деятельности в отчетности, которая размещается в открытом доступе, с тем чтобы внешние пользовате- ли могли анализировать данные и принимать решения о ходе сотрудничества. При анализе финансовой отчетности компаний важным моментом является расчет финан- 
совых показателей. Для определения положения, в котором находится компания, необходимо проведение анализа показателя рентабельности, который отражает эффективность использования как собственного капитала, так и активов в целом, а также преобладание рентабельности собственного капитала над рентабельностью активов, или наоборот. Любая компания в сфере ретейла обладает оборотными средствами, следовательно, важно отслеживать через показатель оборачиваемости, насколько эффективно работает данный актив компании. В свою очередь активы могут быть сформированы за счет заемных средств, что ведет в определенных объемах к потере финансовой независимости. Таким образом, показатели финансовой устойчивости позволяют не допустить потери контроля со стороны менеджмента компании над ее деятельностью и перехода управления компании под руководство кредиторов.

Кроме того, следует определить уровень финансового рычага, который отражает, насколько эффективно используются заемные средства, приносят ли они компании выгоду или, наоборот, способствуют тому, что компания выплачивает больше процентов, чем получает выгоды от своей деятельности. Таким образом, на основе анализа рассчитанных за период времени тенденций показателей рентабельности, оборачиваемости и финансовой устойчивости можно выявить узкие места внутри компании, которые тормозят ее развитие, проследить за тем, какие показатели и в какой период способствуют снижению результативности. Следовательно, на основании выявленных точек торможения развития компании предлагаются направления, следуя которым компании могут, изменив свою текущую политику, повысить эффективность деятельности.

На рациональность управления активами компании существенное влияние оказывает такой показатель, как рентабельность активов. Данный показатель представляет собой отдачу от использования всех активов компании и отражает возможность компании генерировать прибыль, не принимая во внимание структуру капитала [5. - С. 58]. В результате расчета данного показателя получается величина чистой прибыли с каждого рубля, вложенного в активы организации. Показатель рассчитывается по следующей формуле:

$$
R O A=\frac{\text { Чистая прибыль }}{\text { Средняя величинаактивов }} 100 \% .
$$

В табл. 1 представлены данные рентабельности активов по каждой рассмотренной компании за период с 2015 по 2019 г.

Т а блица 1

Рентабельность активов (в \%)

\begin{tabular}{|l|c|c|c|c|c|}
\hline \multicolumn{1}{|c|}{ Компания } & $\mathbf{2 0 1 5}$ & $\mathbf{2 0 1 6}$ & $\mathbf{2 0 1 7}$ & $\mathbf{2 0 1 8}$ & $\mathbf{2 0 1 9}$ \\
\hline ПАО «Магнит» & 33,56 & 23,16 & 27,21 & 20,94 & 22,96 \\
\hline ПАО «Детский мир» & 7,81 & 12,37 & 10,47 & 11,85 & 12,25 \\
\hline ПАО «М.Видео» & 32,79 & 1,01 & 1,48 & 1,74 & 129,70 \\
\hline ООО «Лента» & 16,75 & 5,17 & 3,15 & 2,17 & 3,47 \\
\hline
\end{tabular}

Согласно данным компании TestFirm, рассчитанным на основании исследования 7418 компаний с выручкой от 120 до 800 млн рублей в сфере розничной торговли, показатель рентабельности активов находился в пределах от 5,1\% в 2015 г. до 6,5\% в 2019 г. ${ }^{1}$ У компаний, выручка кото-

\footnotetext{
${ }^{1}$ URL: https:/ / www.testfirm.ru/otrasli/47/?size=3
}

рых в сфере розничной торговли составляет свыше 2 млрд рублей, рентабельность активов находилась в пределах от 2,8\% в 2015 г. до 4,6\% в 2019 г., просаживаясь до 2,9\% в 2017 г. и 1,9\% в 2018 г. ${ }^{2}$

ПАО «Магнит» и ПАО «М.Видео» относятся к компаниям, выручка которых ле-

2 URL: https:/ / www.testfirm.ru/otrasli/47/?size=5 
жит в интервале от 120 до 800 млн рублей, а ПАО «Детский мир» и ООО «Лента» свыше 2 млрд рублей. Таким образом, анализируя нормативные значения по отрасли с полученными значениями по каждой компании, можно отметить, что рентабельность активов ПАО «Магнит» на протяжении всего периода в 4,5-6 раз превышает нормативный показатель. Это свидетельствует о том, что компания эффективно использует активы, получая с каждого вложенного рубля свыше 20,94 копейки прибыли, превышая нормативное значение по отрасли для компаний со схожей выручкой.

Показатель рентабельности активов ПАО «М.Видео» неоднозначный: в 2015 г. он был в 6 раз выше нормы, однако в последующие три года находился значительно ниже нормы. Это связано с тем, что именно с 2016 по 2018 г. у компании отсутствовали поступления от участия в других организациях, а именно выплачиваемые дивиденды. Это приводило к тому, что чистая прибыль компании снижалась в десятки раз, а активы находились приблизительно в одном и том же диапазоне и не испытывали сильных колебаний. Таким образом, эффективность использования активов в данный промежуток времени была минимальной. Однако уже в 2019 г. доходы от участия в других организациях были выплачены, и чистая прибыль возросла в 119,1 раза в сравнении с предыдущим годом. При этом наблюдалась колоссальная эффективность использования активов, которая составляла 129,7 копейки с каждого вложенного рубля.

Рентабельность активов компаний с выручкой свыше 2 млрд рублей практически во все периоды находится в пределах нормативных значений. Компания ПАО «Детский мир» умело управляет активами: она продает большое количество товаров, получая с каждым годом все больше и больше выручки. Валовая прибыль компании также значительно выросла за данный промежуток времени. Имея строение по принципу матрешки, каждый уровень прибыли из года в год растет. При этом растет и уровень активов (в 1,5 раза с 2015 по 2019 г.), и уровень чистой прибыли (в 28,5 раз за аналогичный период). Это свидетельствует о том, что чистая прибыль компании прирастает из года в год быстрее, чем активы, позволяя компании получать от 7,81 до 12,25 копейки с каждого вложенного рубля.

Рентабельность активов ООО «Лента» постепенно падает - с 16,75 копейки с рубля в 2015 г. до 3,47 копейки в 2019 г. В 2015 г. компания получила высокие доходы от участия в других организациях, которые в последующие годы перестали приносить денежные средства. Это в свою очередь оказало воздействие на чистую прибыль, которая упала в 2016 г. по сравнению с 2015 г. в 2,72 раза и продолжала оставаться в пределах 5-9 млрд рублей в сравнении с 26,86 млрд рублей в 2015 г. Активы компании в 2016 г. в сравнении с 2015 г. наоборот возросли в 1,27 раза, затем ежегодно прирастая на $11 \%$. В сравнении с чистой прибылью, которая изменяется скачкообразно, активы имеют четкую тенденцию к росту. Таким образом, рентабельность активов ООО «Лента» изменяется скачкообразно, находясь по большей части в пределах нормативного значения.

Структура пассивов состоит из собственного капитала и обязательств. В отличие от рентабельности активов, которая отражает эффективность использования всего капитала, рентабельность собственного капитала характеризует эффективность отдачи от собственного капитала [1. - С. 111]. Данный показатель представляет интерес для собственника бизнеса, в первую очередь отражая, насколько эффективно используется эта часть пассивов. Рентабельность собственного капитала рассчитывается по следующей формуле:

$$
R O E=\frac{\text { Чистая прибыль }}{\text { Собственньй капитал }} 100 \% .
$$

В табл. 2 приведены рассчитанные данные показателя рентабельности собственного капитала за период с 2015 по 2019 г. по каждой компании. 
Рентабельность собственного капитала (в \%)

\begin{tabular}{|l|c|c|c|c|c|}
\hline \multicolumn{1}{|c|}{ Компания } & $\mathbf{2 0 1 5}$ & $\mathbf{2 0 1 6}$ & $\mathbf{2 0 1 7}$ & $\mathbf{2 0 1 8}$ & $\mathbf{2 0 1 9}$ \\
\hline ПАО «Магнит» & 50,46 & 47,11 & 44,99 & 23,46 & 28,80 \\
\hline ПАО «Детский мир» & 73,00 & 161,15 & 97,34 & 125,70 & 121,90 \\
\hline ПАО «М.Видео» & 34,81 & 1,27 & 1,47 & 1,82 & 92,91 \\
\hline ООО «Лента» & 78,68 & 22,43 & 13,67 & 9,23 & 14,11 \\
\hline
\end{tabular}

Согласно данным, рассчитанным компанией TestFirm на основании исследования 7418 компаний с выручкой от 120 до 800 млн рублей в сфере розничной торговли, показатель рентабельности собственного капитала находился в пределах от 24,8\% в 2017 г. и до 29,4\% в 2019 г., достигая своего максимума в 2016 г. ${ }^{1}$ Для крупных компаний, выручка которых составляет свыше 2 млрд рублей, данный показатель находился в пределах от 18\% в 2018 г. до $26,6 \%$ в 2019 г. ${ }^{2}$

Анализируя показатели ПАО «Магнит», следует отметить, что рентабельность собственного капитала компании в исследуемый период находилась в пределах нормативных значений - от 24,8 до 29,4\% и даже выше на всем промежутке, что свидетельствует о ведении разумной политики в отношении собственного капитала компании. Компания ПАО «М.Видео», находясь в одном списке с ПАО «Магнит» по уровню выручки, проседает в плане управления собственным капиталом. Это связано с упавшей на 97,6\% выручкой в 2016 г. по сравнению с 2015 г. Выручка значительно сокращалась в период с 2016 по 2018 г., поскольку отсутствовали доходы от участия в других организациях, которые имели значительный вес в отчете о финансовых результатах, составляя 95,9\% от прибыли до налогообложения. Собственный капитал при этом также снизился в 2016 г. по сравнению с 2015 г. на 33,9\%, что значительно ниже, чем падение чистой прибыли на 97,6\%. Собственный капитал компании в период с 2016 по 2018 г. оставался в пределах 6,3-6,9 млрд рублей. Однако в 2019 г.

1 URL: https://www.testfirm.ru/otrasli/47/?size=3 2 URL: https:/ / www.testfirm.ru/otrasli/47/?size=5 нераспределенная прибыль выросла на 2 420,44\% по сравнению с 2018 г., что увеличило собственный капитал на 233,8\% за этот период. Рост нераспределенной прибыли неразрывно связан с ростом чистой прибыли, которая возросла в 2019 г. на 11 910,9\% по сравнению с предыдущим годом. Такой рост чистой прибыли и собственного капитала способствовал повышению рентабельности собственного капитала до 92,91 копейки на каждый рубль собственного капитала.

Рентабельность ПАО «Детский мир» превышает нормативное значение от 18 до $26,6 \%$ более чем в 4 раза. Это свидетельствует о том, что компания эффективно управляет собственным капиталом, который приносит ей свыше 73 копеек на каждый вложенный рубль собственного капитала.

Показатель рентабельности собственного капитала компании ООО «Лента» постепенно уменьшается с 78,68 копейки до 14,11 копейки на рубль собственного капитала. Это связано с тем, что доходы от участия в других организациях снизились с 19,8 млрд рублей до 0, снизив при этом чистую прибыль на 63,25\% в 2016 г. Собственный капитал компании в этот период вырос на 128,9\% - с 34,1 млрд до 44 млрд рублей. Это значительно снизило рентабельность собственного капитала в 2016 г. - до 22,43 копейки с рубля. С 2016 по 2018 г. чистая прибыль компании снижалась из-за отсутствия поступлений от участия в других организациях и снизившихся прочих доходов. Это в свою очередь повлияло на то, что рентабельность собственного капитала в этот период значительно снизилась, достигнув 9,23 копейки с вложенного рубля. 
Заемный капитал, несмотря на условия платности, может стоить для компании дешевле [4. - С. 347]. Более того, рост доли заемного капитала влечет за собой и увеличение доходности собственного капитала за счет экономии на налоговых выплатах и тем самым уменьшение налогооблагаемой прибыли компании. Однако следует учитывать, что при увеличении заемного финансирования будет расти и эффект

$$
\text { Эффект финансового рычага }=\left(1-\mathrm{C}_{\mathrm{HII}}\right) \cdot(R O A-i) \cdot \frac{3 \mathrm{~K}}{\mathrm{CK}^{\prime}},
$$

где $\mathrm{C}_{\text {нп }}$ - ставка налога на прибыль;

3К - заемный капитал;

$R O A$ - рентабельность активов;

$i$ - размер процентов за кредит, уплачиваемый за использование заемного капитала; финансового рычага, который представляет собой фактор изменения финансовых результатов, выражаемых в структуре источников финансирования. При высокой доле заемного капитала наблюдается высокое значение финансового рычага и финансового риска. Расчет эффекта финансового рычага производится по следующей формуле [2. - С. 24]:
СК - собственный капитал.

Проценты за кредит, уплачиваемые за использование заемного капитала, определяются по формуле

$$
C_{d}=\frac{\text { Проценты к уплате }}{\text { (Долгосрочные обязательства }+ \text { Краткосрочные обязательства) }} 100 \% \text {. }
$$

Ставку налога на прибыль рассчитаем по формуле

$$
\begin{aligned}
& \text { Эффавка налога } \\
& \text { Станная }
\end{aligned}=\frac{\text { Налог на прибыль }}{\text { Прибыль до налогообложения }} 100 \% \text {. }
$$

Стоимость привлечения заемного капитала (в \%)

\begin{tabular}{|l|c|c|c|c|c|}
\hline \multicolumn{1}{|c|}{ Компания } & $\mathbf{2 0 1 5}$ & $\mathbf{2 0 1 6}$ & $\mathbf{2 0 1 7}$ & $\mathbf{2 0 1 8}$ & $\mathbf{2 0 1 9}$ \\
\hline ПАО «Магнит» & 5,74 & 9,28 & 5,90 & 3,29 & 3,06 \\
\hline ПАО «Детский мир» & 4,79 & 4,24 & 4,01 & 2,91 & 3,61 \\
\hline ПАО «М.Видео» & 0,00 & 0,00 & 0,00 & 0,00 & 0,00 \\
\hline ООО «Лента» & 8,90 & 5,95 & 6,35 & 5,14 & 6,05 \\
\hline
\end{tabular}

\begin{tabular}{|c|c|}
\hline \multicolumn{2}{|c|}{ ПАО «Магнит» } \\
\hline Капитал & 99,80 \\
\hline Долгосрочные обязательства & 0 \\
\hline Краткосрочные обязательства & 0,20 \\
\hline \multicolumn{2}{|c|}{ ПАО «Детский мир» } \\
\hline Капитал & 9,80 \\
\hline Долгосрочные обязательства & 13,90 \\
\hline Краткосрочные обязательства & 76,30 \\
\hline \multicolumn{2}{|c|}{ ПАО «М.Видео» } \\
\hline Капитал & 99,80 \\
\hline Долгосрочные обязательства & 0 \\
\hline Краткосрочные обязательства & 0,20 \\
\hline \multicolumn{2}{|c|}{ ООО «Лента» } \\
\hline Капитал & 23,30 \\
\hline Долгосрочные обязательства & 32,60 \\
\hline Краткосрочные обязательства & 44,10 \\
\hline
\end{tabular}

Т а блица 4

Структура капитала компаний (в \%) 
Эффективная ставка налога (в \%)

\begin{tabular}{|l|c|c|c|c|c|}
\hline \multicolumn{1}{|c|}{ Компания } & $\mathbf{2 0 1 5}$ & $\mathbf{2 0 1 6}$ & $\mathbf{2 0 1 7}$ & $\mathbf{2 0 1 8}$ & $\mathbf{2 0 1 9}$ \\
\hline ПАО «Магнит» & 3,07 & 4,66 & 3,41 & 5,43 & 0,50 \\
\hline ПАО «Детский мир» & 29,55 & 25,01 & 23,00 & 17,86 & 20,43 \\
\hline ПАО «М.Видео» & 1,24 & 37,41 & 32,79 & 31,59 & 0,42 \\
\hline ООО «Лента» & 2,01 & 8,72 & 7,78 & 16,14 & 26,30 \\
\hline
\end{tabular}

Эффект финансового рычага (в \%)

Т а блица 6

\begin{tabular}{|l|c|c|c|c|c|}
\hline \multicolumn{1}{|c|}{ Компания } & $\mathbf{2 0 1 5}$ & $\mathbf{2 0 1 6}$ & $\mathbf{2 0 1 7}$ & $\mathbf{2 0 1 8}$ & $\mathbf{2 0 1 9}$ \\
\hline ПАО «Магнит» & 13 & 6 & 10 & 8 & 9 \\
\hline ПАО «Детский мир» & 20 & 56 & 46 & 68 & 63 \\
\hline ПАО «М.Видео» & 0,0649 & 0,0013 & 0,0020 & 0,0024 & 0,2588 \\
\hline ООО «Лента» & 25 & -2 & -10 & -8 & -6 \\
\hline
\end{tabular}

Анализ полученных данных отчетливо показал, что компания, в структуре пассивов которой всего лишь 0,2\% составляют заемные источники финансирования, обладает практически нулевым эффектом финансового рычага. То есть использование в таком объеме заемных источников позволило компании повысить рентабельность собственного капитала всего на $0,0649 \%$ в 2015 г., на 0,0013\% в 2016 г., на $0,002 \%$ в 2017 г., на 0,0024\% в 2018 г. и на $0,26 \%$ в 2019 г.

Самым высоким эффектом финансового рычага обладает ПАО «Детский мир», которое повышает рентабельность собственного капитала за счет использования заемных средств (на 20\% в 2015 г., на $56 \%$ в 2016 г., на $46 \%$ в 2017 г., на $68 \%$ в 2018 г. и на $63 \%$ в 2019 г.). Такое положение компании свидетельствует о том, что рентабельность активов значительно превышает ставку по кредитам, что в свою очередь позволяет заемным средствам повышать рентабельность собственного капитала.

Компания ООО «Лента» согласно проведенному анализу полученных данных находится в трудном положении, поскольку рентабельность собственного капитала компании ниже ставки по кредитам, о чем свидетельствует отрицательное значение эффекта финансового рычага. При этом привлечение заемных средств ведет к снижению рентабельности собственного капитала. Таким образом, компании ООО «Лента» следует изменить структуру капитала, в соответствии с которой рентабельность активов будет превышать ставку по кредитам. В противном случае в дальнейшей перспективе компания столкнется с вероятностью возникновения банкротства.

Финансовый рычаг и финансовая устойчивость являются неким противоречием друг для друга, состоящим в том, что рост финансового рычага в структуре пассивов влечет за собой рост рентабельности собственного капитала [7. - С. 36]. Собственный капитал в свою очередь выступает одним из важных критериев для принятия эффективных финансовых решений. Однако в то же время увеличение заемного капитала в структуре баланса влечет снижение финансовой устойчивости компании и создает повышенный финансовый риск. Основная задача в таком случае состоит не только в нахождении оптимального соотношения между собственным и заемным капиталом, минимизирующего средневзвешенную цену капитала (WACC), но и в создании подходящих условий для сохранения и даже роста финансовой устойчивости компании. 
Средневзвешенная цена капитала выступает основным индикатором, отражающим приемлемость структуры источников. Финансовый менеджер выберет такую структуру источников финансирования, при которой средневзвешенная цена будет минимальной.

Помимо принципа минимальной средневзвешенной стоимости необходимо принимать во внимание и принцип достаточной отдачи деятельности компании, которая должна быть выше цены его капитала. Если при условии инвестирования средств не происходит необходимого наращения, вытекающего из цены капита- ла, то возникает вероятность экономической нежизнеспособности. В таком случае финансовому менеджеру следует выбирать такие источники финансирования, при которых не происходит максимального исчерпывания всех доходов компании, а наоборот, происходят рост и развитие [6. C. 736].

Таким образом, на основании вышеприведенных данных структуры капитала, рентабельности собственного капитала, стоимости заемных источников и эффективной налоговой ставки рассчитаем средневзвешенную стоимость капитала (табл. 7).

Средневзвешенная стоимость капитала (в \%)

\begin{tabular}{|l|c|c|c|c|c|}
\hline \multicolumn{1}{|c|}{ Компания } & $\mathbf{2 0 1 5}$ & $\mathbf{2 0 1 6}$ & $\mathbf{2 0 1 7}$ & $\mathbf{2 0 1 8}$ & $\mathbf{2 0 1 9}$ \\
\hline ПАО «Магнит» & 36,14 & 34,90 & 32,46 & 16,97 & 20,59 \\
\hline ПАО «Детский мир» & 10,20 & 18,66 & 12,32 & 14,47 & 14,54 \\
\hline ПАО «М.Видео» & 34,74 & 1,26 & 1,47 & 1,82 & 92,72 \\
\hline ООО «Лента» & 25,02 & 9,39 & 7,68 & 5,46 & 6,70 \\
\hline
\end{tabular}

В ходе своей деятельности компании строят стратегию на будущие периоды, в которой в качестве индикатора управления собственным и заемным капиталом применяется оценка динамики изменения стоимости компании. Для реализации та- кой задачи WACC сопоставляется с рентабельностью активов ROA. Для сравнения показателей WACC и ROA вычтем из данных WACC, представленных в табл. 7, значение $R O A$ (табл. 8). Полученные данные представлены в табл. 9.

Рентабельность активов (в \%)

\begin{tabular}{|l|c|c|c|c|c|}
\hline \multicolumn{1}{|c|}{ Компания } & $\mathbf{2 0 1 5}$ & $\mathbf{2 0 1 6}$ & $\mathbf{2 0 1 7}$ & $\mathbf{2 0 1 8}$ & $\mathbf{2 0 1 9}$ \\
\hline ПАО «Магнит» & 33,56 & 23,16 & 27,21 & 20,94 & 22,96 \\
\hline ПАО «Детский мир» & 7,81 & 12,37 & 10,47 & 11,85 & 12,25 \\
\hline ПАО «М.Видео» & 32,79 & 1,01 & 1,48 & 1,74 & 129,70 \\
\hline ООО «Лента» & 16,75 & 5,17 & 3,15 & 2,17 & 3,47 \\
\hline
\end{tabular}

Сравнение WACC и ROA (в \%)

\begin{tabular}{|l|c|c|c|c|c|}
\hline \multicolumn{1}{|c|}{ Компания } & $\mathbf{2 0 1 5}$ & $\mathbf{2 0 1 6}$ & $\mathbf{2 0 1 7}$ & $\mathbf{2 0 1 8}$ & $\mathbf{2 0 1 9}$ \\
\hline ПАО «Магнит» & 2,58 & 11,74 & 5,25 & $-3,97$ & $-2,37$ \\
\hline ПАО «Детский мир» & 2,38 & 6,29 & 1,85 & 2,62 & 2,29 \\
\hline ПАО «М.Видео» & 1,95 & 0,26 & $-0,01$ & 0,08 & $-36,98$ \\
\hline ООО «Лента» & 8,27 & 4,21 & 4,53 & 3,29 & 3,23 \\
\hline
\end{tabular}


Исходя из результатов сравнения можно сделать следующие выводы:

- в случае, когда WACC превышает $R O A$, это свидетельствует о снижении экономической добавленной стоимости и общей потере стоимости компании;

- если WACC меньше ROA, это показывает, что активы используются эффективно и стоимость компании растет.

Как видно из приведенных данных, WACC в большинстве случаев превышает показатель рентабельности активов. Это свидетельствует о том, что компании из года в год снижают экономическую добавленную стоимость и теряют стоимость компании. Таким образом, компаниям следует пересмотреть политику формирования структуры капитала, оказывающую воздействие как на средневзвешенную стоимость капитала, так и на чистую прибыль, входящую в состав расчетов рента- бельности активов. Компаниям следует повышать рентабельность активов путем повышения чистой прибыли. В таком случае им необходимо пересмотреть коммерческие и управленческие расходы и при измененной структуре капитала учесть новый объем выплачиваемых процентов по заемным источникам, что в целом окажет воздействие на итоговый результат чистой прибыли и повлияет на рентабельность активов.

Не менее важное значение в ходе анализа деятельности компании имеет анализ показателей финансовой устойчивости, характеризующих устойчивость компании, наличие средств, позволяющих компании поддерживать свою деятельность в течение определенного промежутка времени [3. - С. 152]. Расчеты финансовых показателей представлены в табл. 10.

Та блица 10

Показатели финансовой устойчивости (в \%)

\begin{tabular}{|l|c|c|c|}
\hline \multicolumn{1}{|c|}{ Компания } & $\begin{array}{c}\text { Коэффициент } \\
\text { автономии }\end{array}$ & $\begin{array}{c}\text { Коэффициент обеспеченности } \\
\text { собственными оборотными } \\
\text { средствами }\end{array}$ & $\begin{array}{c}\text { Коэффициент } \\
\text { покрытия } \\
\text { инвестиций }\end{array}$ \\
\hline Нормативное значение & $45-70$ & Не менее 10 & Не менее 70 \\
\hline ПАО «Магнит» & 68,08 & 53,34 & 87,46 \\
\hline ПАО «Детский мир» & 9,83 & 6,72 & 23,73 \\
\hline ПАО «М.Видео» & 99,76 & 99,58 & 99,76 \\
\hline ООО «Лента» & 23,34 & 5,97 & 55,99 \\
\hline
\end{tabular}

Как видно из данных табл. 10, оптимальное соотношение собственного и заемного капитала только у ПАО «Магнит»: собственный капитал составляет 68,1\% в общем капитале организации в противовес заемным источникам в 21,9\%. Руководство ПАО «М.Видео» слишком осторожно относится к привлечению заемных денежных средств: собственный капитал составляет 99,8\% в общем капитале организации. Показатели автономии ПАО «Детский мир» и ООО «Лента» свидетельствуют о недостаточной доле собственного капитала в общем капитале компании, составляя менее $23,34 \%$ от общего объема.
Коэффициент обеспеченности собственными оборотными средствами превышает нормативное значение в 10\% в ПАО «Магнит» и ПАО «М.Видео». Это свидетельствует о том, что свыше $10 \%$ оборотных активов компании сформировано за счет собственных средств. В случаях ПАО «Детский мир» и ООО «Лента» всего лишь 6,72 и 5,97\% оборотных средств соответственно сформированы за счет собственных источников, остальная часть приходится на заемные источники. Несмотря на более низкую стоимость заемных средств, превышение заемных источ- 
ников над собственными может приводить к потере контроля над компанией.

Коэффициент покрытия инвестиций показывает, какая часть активов формируется за счет устойчивых источников - собственного капитала и долгосрочных обязательств. Значение данного коэффициента значительно ниже нормативного (70\%) у ПАО «Детский мир» и ООО «Лента» 23,73 и 55,99\% соответственно. Такое положение свидетельствует о преобладании краткосрочных источников финансирования деятельности компании. В случае возникновения таких ситуаций, когда оборотные активы не могут преобразоваться в денежные средства, это отрицательно сказывается на деятельности компании.

Таким образом, ПАО «Детский мир» и ООО «Лента» следует изменить структуру капитала, снизив долю краткосрочных источников. Это будет способствовать повышению коэффициента покрытия инвестиций и коэффициента обеспеченности собственными оборотными средствами.

Проводя анализ финансовой устойчивости компании, следует помнить о таком показателе, как скорость оборота оборотных средств. Данный показатель важен, поскольку чем быстрее оборачиваются оборотные средства, тем больше денежных средств появляется в обороте компании, которыми она может распоряжаться. Таким образом, компания, у которой скорость оборота оборотных средств выше при условии близкой структуры капитала, может иметь большую долю заемных источников в пассивах без риска неплатежеспособности и роста рисков для кредиторов. Следовательно, при условии близкой структуры капитала более высокая скорость оборота оборотных средств способствует тому, что компания выглядит более привлекательно для кредиторов и заимодателей.

Рассмотрим показатели оборачиваемости в днях в разрезе каждой компании (табл. 11-14).

Для отрасли, в которой оперирует ПАО «Магнит», нормальным значением коэффициента оборачиваемости является 153 дня и менее.

Та блица 11

Коэффициент оборачиваемости ПАО «Магнит»

\begin{tabular}{|l|c|c|c|c|c|}
\hline \multicolumn{1}{|c|}{ Показатель } & $\mathbf{2 0 1 5}$ & $\mathbf{2 0 1 6}$ & $\mathbf{2 0 1 7}$ & $\mathbf{2 0 1 8}$ & $\mathbf{2 0 1 9}$ \\
\hline Коэффициент оборачиваемости & 0,00933 & 0,01430 & 0,02450 & 0,00973 & 0,01101 \\
\hline Оборачиваемость в днях & 39129,68 & 25518,45 & 14894,99 & 37517,68 & 33144,25 \\
\hline
\end{tabular}

Данные об оборачиваемости активов в среднем за 5 лет свидетельствуют о том, что ПАО «Магнит» получило выручку, равную сумме всех имеющихся активов, за 30041 календарный день, или 82 года. При этом в среднем требуется 1 день, чтобы расходы компании по обычным видам деятельности составили величину среднегодового остатка материально-производственных запасов. Такие критические показатели свидетельствуют о том, что основная деятельность компании находится в плохом состоянии. Компания выживает исключительно за счет доходов от участия в других организациях, которые в 2019 г. превышали выручку в 60,2 раза. Компании следует детальнее отнестись к части оборотных средств, основной статьей которой являются финансовые вложения, составлявшие в 2019 г. 94,5\% от оборотных средств.

Для отрасли, в которой функционирует ПАО «Детский мир», нормальное значение коэффициента оборачиваемости составляет не более 86 дней. 
Коэффициент оборачиваемости ПАО «Детский мир»

\begin{tabular}{|l|c|c|c|c|c|}
\hline \multicolumn{1}{|c|}{ Показатель } & $\mathbf{2 0 1 5}$ & $\mathbf{2 0 1 6}$ & $\mathbf{2 0 1 7}$ & $\mathbf{2 0 1 8}$ & $\mathbf{2 0 1 9}$ \\
\hline Коэффициент оборачиваемости & 2,81 & 2,55 & 2,62 & 2,58 & 2,57 \\
\hline Оборачиваемость в днях & 122,84 & 135,32 & 131,56 & 133,52 & 134,07 \\
\hline
\end{tabular}

Данные об оборачиваемости активов в среднем за весь рассматриваемый период свидетельствуют о том, что компания получает выручку, равную сумме всех имеющихся активов, за 131 календарный день. О размере материально-производственных запасов можно судить по следующему соотношению: в среднем требуется 120 дней, чтобы расходы по обычным видам деятельности составили величину среднегодового остатка запасов. В среднем оборачиваемость оборотных средств ПАО «Детский мир» превышает нормативное значение в полтора раза, показывая недостаточно высокую скорость оборота оборотных средств. Преобладающей статьей оборотных средств выступают запасы, занимающие $78,1 \%$ от общего объема оборотных средств. Относительно высокий уровень запасов может отвлекать денежные средства от оборота и тормозить развитие компании.

Таким образом, ПАО «Детский мир» следует внимательнее отнестись к структуре оборотных средств.

Для отрасли, в которой функционирует ПАО «М.Видео», нормальное значение коэффициента оборачиваемости составляет 173 дня и менее.

Коэффициент оборачиваемости ПАО «М.Видео»

\begin{tabular}{|l|c|c|c|c|c|}
\hline \multicolumn{1}{|c|}{ Показатель } & $\mathbf{2 0 1 5}$ & $\mathbf{2 0 1 6}$ & $\mathbf{2 0 1 7}$ & $\mathbf{2 0 1 8}$ & $\mathbf{2 0 1 9}$ \\
\hline Коэффициент оборачиваемости & 0,02 & 0,04 & 0,16 & 0,55 & 0,05 \\
\hline Оборачиваемость в днях & 18329,99 & 9381,42 & 2334,56 & 662,49 & 7672,86 \\
\hline
\end{tabular}

Данные об оборачиваемости активов в среднем за весь анализируемый период свидетельствуют о том, что компания получает выручку, равную сумме всех имеющихся активов, за 7676 календарных дней, или 21 год. Такое критическое положение возникло у компании за счет преобладания дебиторской задолженности в структуре оборотных активов, которая составляет $88,9 \%$ от общей структуры оборотных активов. Это отвлекает денежные средства от оборота. При этом возникает вероятность невозврата данных денежных средств с течением времени, что прямым образом может отражаться на чистой прибыли. Таким образом, компании следует более детально отнестись к политике по формированию дебиторской задолженности.

Для отрасли, в которой функционирует ООО «Лента», нормальное значение коэффициента оборачиваемости оборотных средств составляет не более 86 дней.

Оборачиваемость активов в среднем за 5 лет показывает, что компания получает выручку, равную сумме всех имеющихся активов, за 73 календарных дня. Оборачиваемость компании соответствует нормативному значению, что свидетельствует об эффективном управлении оборотными средствами. 
Коэффициент оборачиваемости ООО «Лента»

\begin{tabular}{|l|c|c|c|c|cc|}
\hline \multicolumn{1}{|c|}{ Показатель } & $\mathbf{2 0 1 5}$ & $\mathbf{2 0 1 6}$ & $\mathbf{2 0 1 7}$ & $\mathbf{2 0 1 8}$ & $\mathbf{2 0 1 9}$ \\
\hline Коэффициент оборачиваемости & 4,89 & 5,28 & 5,69 & 5,41 & 3,98 \\
\hline Оборачиваемость в днях & 74,67 & 69,09 & 64,15 & 67,43 & 91,76 \\
\hline
\end{tabular}

Подведем итоги по каждой компании по всем показателям.

ПАО «М.Видео» полностью формирует свои внеоборотные и оборотные активы за счет собственного капитала, упуская возможность использования более дешевого заемного капитала, что влечет за собой высокие значения коэффициента автономии, коэффициента обеспеченности собственными оборотными средствами и коэффициента покрытия инвестиций. Все указанные показатели находятся за пределами нормативных значений, что свидетельствует о том, что компания упускает возможность более оптимального использования как собственных, так и заемных средств.

Показатель рентабельности активов неоднозначный за счет отсутствия поступлений от участия в других организациях. Компания отстает от нормативов в плане управления собственным капиталом в связи с отсутствием доходов от участия в других организациях. В структуре пассивов компании всего лишь 0,2\% составляют заемные источники финансирования, следовательно, она обладает практически нулевым эффектом финансового рычага.

Заемные источники ПАО «Магнит» составляют $31,9 \%$, а на собственный капитал приходится 68,1\%, упуская возможность использования более дешевого заемного капитала. В компании очевидно преобладание внеоборотных активов над оборотными, что нехарактерно для сферы розничной торговли. Внутри компании преобладает инвестиционная деятельность над операционной.

Рентабельность активов ПАО «Магнит» на протяжении всего периода в 4,5-6 раз превышает нормативный показатель. Это свидетельствует о том, что компания эффективно использует активы. Рентабельность собственного капитала компании находится в пределах нормативных значений на всем промежутке, что свидетельствует о ведении разумной политики в отношении собственного капитала.

В структуре ПАО «Детский мир» преобладают краткосрочные обязательства. Компания умело управляет активами, получая с каждым годом все больше выручки. Рентабельность ПАО «Детский мир» превышает нормативное значение более чем в 4 раза. Это свидетельствует о том, что компания эффективно управляет собственным капиталом. Она обладает самым высоким эффектом финансового рычага, повышая рентабельность собственного капитала за счет использования заемных средств. Такое положение компании свидетельствует о том, что рентабельность активов значительно превышает ставку по кредитам, что в свою очередь позволяет заемным средствам повышать рентабельность собственного капитала.

Показатели ООО «Лента» практически соответствуют нормативным: $30 \%$ собственного капитала и 70\% заемного. Внутри компании сложилось довольно оптимальное соотношение показателей, поскольку внеоборотные активы полностью могут быть сформированы за счет собственного капитала и долгосрочных обязательств, а все краткосрочные активы могут идти на формирование оборотных активов. Показатель рентабельности собственного капитала ООО «Лента» постепенно уменьшается в связи со снижением доходов от участия в других организациях. Рентабельность активов ООО «Лента» постепенно падает из-за отсутствия доходов 
от участия в других организациях. Компания находится в трудном положении, поскольку рентабельность собственного капитала компании ниже ставки по кредитам, о чем свидетельствует отрицательное значение эффекта финансового рычага. В таком случае привлечение заемных средств ведет к снижению рентабельности собственного капитала. Таким образом, компании следует изменить структуру капитала, в соответствии с которой рентабельность активов будет превышать ставку по кредитам, в противном случае в дальнейшем компания столкнется с вероятностью возникновения банкротства.

\section{Список литературы}

1. Бердников А. А. Анализ прибыли и рентабельности организации: теоретический аспект / / Молодой ученый. - 2018. - № 2. - С. 111-113.

2. Грачева Ю. В., Тарасова А. Ю. Особенности налогообложения прибыли в РФ и эффект финансового рычага // Вестник Московского финансово-юридического университета. - 2019. - № 2. - С. 23-33.

3. Захарова Л. Н., Хребтова Т. М., Юферова Н. Ю. Анализ обобщенных коэффициентов оценки финансового состояния организаций и административно-территориальных образований Российской Федерации // Инновации и инвестиции. - 2019. - № 4. С. $184-188$.

4. Зыкова Н. В., Резниченко М. С. Анализ рентабельности предприятия // Молодой ученый. - 2020. - № 3 (293). - С. 347-348.

5. Лекаркина Н. К. Анализ показателя рентабельности активов для основных отраслей экономики / / Оценка инвестиций. - 2020. - № 3 (17). - С. 56-66.

6. Graham J., Smart S. Introduction to Corporate Finance : 3rd edition. - Cengage Learning, 2011.

7. Kumar R. Determinants of Firm's Financial Leverage: A Critical Review // Journal of Contemporary Research in Management. - 2008. - N 3 (1).

\section{References}

1. Berdnikov A. A. Analiz pribyli i rentabelnosti organizatsii: teoreticheskiy aspekt [Analysis of Profit and Profitability of the Organization: Theoretical Aspect]. Molodoy uchenyy [Young Scientist], 2018, No. 2, pp. 111-113. (In Russ.).

2. Gracheva Yu. V., Tarasova A. Yu. Osobennosti nalogooblozheniya pribyli v RF i effekt finansovogo rychaga [Features of Taxation of Profits in the Russian Federation and the Effect of Financial Leverage]. Vestnik Moskovskogo finansovo-yuridicheskogo universiteta [Bulletin of the Moscow Financial and Legal University], 2019, No. 2, pp. 23-33. (In Russ.).

3. Zakharova L. N., Khrebtova T. M., Yuferova N. Yu. Analiz obobshchennykh koeffitsientov otsenki finansovogo sostoyaniya organizatsiy i administrativno-territorialnykh obrazovaniy Rossiyskoy Federatsii [Analysis of Generalized Coefficients for Assessing the Financial Condition of Organizations and Administrative-Territorial Entities of the Russian Federation]. Innovatsii $i$ investitsii [Innovation and Investment], 2019, No. 4, pp. 184-188. (In Russ.).

4. Zykova N. V., Reznichenko M. S. Analiz rentabelnosti predpriyatiya [Analysis of the Profitability of the Enterprise]. Molodoy uchenyy [Young Scientist], 2020, No. 3 (293), pp. 347348. (In Russ.). 
5. Lekarkina N. K. Analiz pokazatelya rentabelnosti aktivov dlya osnovnykh otrasley ekonomiki [Analysis of the Return on Assets Indicator for the Main Sectors of the Economy]. Otsenka investitsiy [Investment Appraisal], 2020, No. 3 (17), pp. 56-66. (In Russ.).

6. Graham J., Smart S. Introduction to Corporate Finance, 3rd edition. Cengage Learning, 2011.

7. Kumar R. Determinants of Firm's Financial Leverage: A Critical Review. Journal of Contemporary Research in Management, 2008, No. 3 (1).

\section{Сведения об авторе}

Ирина Владимировна Просвирякова аспирантка кафедры финансового менеджмента РЭУ им. Г. В. Плеханова. Адрес: ФГБОУ ВО «Российский экономический университет имени Г. В. Плеханова», 117997, Москва,

Стремянный пер., д. 36.

E-mail: prosviriakova.ira@yandex.ru

\section{Information about the author}

Irina V. Prosviriakova

Post-Graduate Student of the Department for Financial Management of the PRUE. Address: Plekhanov Russian University of Economics, 36 Stremyanny Lane, Moscow, 117997, Russian Federation. E-mail: prosviriakova.ira@yandex.ru 